\title{
To what extent do Turkish high school students know about their body organs and organ systems?
}

\author{
Solmaz Aydin ${ }^{1}$
}

\begin{abstract}
This study aimed to determine high school students' familiarity with body organs and knowledge about the systems to which organs belong. It also identifies their misconceptions and deficiencies and discusses their causes. The sample of the study consisted of 244 secondary students. The study used the descriptive survey method. The findings show that the heart, lungs, kidneys and stomach are the best known organs by the students, and that they most often identified organs in the circulatory, respiratory, urinary and digestive systems rather than other systems. In addition, there are no considerable differences between the ninth, tenth, eleventh grade classes and the twelfth grade students' knowledge and misconceptions about organs and organ systems. The most basic misconceptions identified in this study is that a majority of the students who identified the small intestine, liver, pancreas, anus and intestine thought that these organs were parts of the excretory system. In Turkey's educational system, students are taught the urinary system as the excretory system. This leads students to think that these organs are not elements of the digestive system, but those of the excretory system, which is used to defecate the excretions. For this reason, this study will also discuss this situation.
\end{abstract}

Keywords: Biology education; body organs; organ systems; high school students

\section{Introduction}

People having adequate knowledge about their bodies and body functions could help them to answer many questions in their daily lives, to solve problems and give them more accurate ideas about their health. Therefore, biology courses in primary and secondary schools aim to teach this subject to students. Students' learning about biology from an early age is the foundation for the education they will receive and the information they will learn throughout the rest of their lives. Moreover, gaining awareness and knowledge in this field will contribute to their developing into scientifically literate individuals. Today, one of the main goals of our education system is to raise children to be scientifically literate individuals. The researchers decided to conduct this study because they think that a student who is scientifically literate should be informed about the functioning of their own body. This research focuses on organs and systems in the human body and discusses their place in the biology curriculum.

An analysis of the current situation of biology, a major field of science, in Turkey indicates that students have difficulty understanding many of its basic subjects (Bahar, 2002; Güneş \& Güneş, 2005) or they have misconceptions about them (Atılboz, 2004; Güngör \& Özgür, 2009; Tekkaya, Çapa \& Yılmaz, 2000; Yeşilyurt \& Gül, 2012). Body organs and systems is one of these

\footnotetext{
${ }^{1}$ Assist. Prof. Dr., Kafkas University, Education Faculty, Department of Science Education, solmazaydn@gmail.com
} 
Aydın, S. (2016). To what extent do Turkish high school students know about their body organs and organ systems? International Journal of Human Sciences, 13(1), 1094-1106. doi:10.14687/ijhs.v13i1.3498

subjects. Teaching this subject will help students get to know their own bodies and have an opinion about the place of these functions in human health.

A review of the relevant literature shows that Reiss and Tunnicliffe (2001) determined the knowledge level of children from various age groups about organs and systems. They used the drawing method to acquire these results. Children were asked to draw what is inside our bodies. These drawings were analysed and interpreted. Each drawing made by the students was scored using a seven-point ranking system. The results indicated that the knowledge levels of students increased in direct proportion to their age. It was also determined that few students could successfully and completely draw the organ systems. The researchers determined that digestive system and respiratory system were the systems that were drawn most successfully by the students. The circulatory system (especially the heart) and the skeletal system were the most frequently drawn systems.

Reiss, Tunnicliffe, Andersen, Bartoszeck et al. (2002) used the drawing method in their survey and asked students at 7 and 15 years of age to draw what was inside the body. They analysed and interpreted their drawings. The researchers analysed the drawings using the seven-point ranking system that was also used by Reiss and Tunnicliffe (2001). The research results indicated that students at age 7 had a broad knowledge about the internal structure of the body and were aware of the diversity of body organs. Unfortunately, 15 year-old students' knowledge about body organs was quite insufficient as they were expected to have been at a higher level.

Özsevgeç (2007) used the drawing and writing method to collect the data. She aimed to investigate students' understanding of their internal bodies. The data were gathered from grade 6 and grade 8 students and students' drawings of the organs were analyzed by means of the organs' location, shape and function. The researchers gave an outline of a body map to each student and asked them to draw the organs in their bodies and write down their functions. Their drawings were analysed in three stages: (i) the existence or nonexistence of the organ, (ii) the location and shape of the organ and (iii) the function of the organ. The researchers did not consider minor details. The study results revealed that most students knew the names of the organs, yet lacked information about their location, shape and function. It was also found that students did not have sufficient knowledge about the connections between the organs in a single body system.

Jaakkola and Slaughter (2002) used the interview method in a survey of children between 4 and 10 years of age. Children were questioned about 13 body parts (heart, brain, muscles, eyes, teeth, lungs, bones, blood, hands, stomach, skin, nerves and tongue) and they were asked to draw these organs on the outline of a body map given to them. The researchers checked the students' answers for the function and location of the organ and encoded the responses. Their results showed that there was a significant increase in 4 and 8 year-old students' knowledge about our body, and that there was a qualitative change in the reasoning of 4 and 6 year-old students. Similarly, Gellert (1962) interviewed 4-16 year-old children who were staying in a hospital. Students were asked about body organs and systems. The research determined that children had many misconceptions about body organs, and that their knowledge about the body increased steadily until the age of 9 .

In these studies of children's knowledge of body organs, the most common method used by researchers appears to be the drawing method, asking students or teachers to make drawings and then analysing them (Patrick \& Tunnicliffe, 2010; Reiss \& Tunnicliffe, 2001; Reiss, Tunnicliffe, Andersen, Bartoszeck et al., 2002). The interview method is also used (Gellert, 1962; Jaakkola \& Slaughter, 2002; Johnson \& Wellman, 1982). However, although no studies were found that collected information from written responses, this technique has been used along with other methods in some studies (see: Prokop \& Fancovicova, 2006). In this study, the author did not use the drawing method, which is commonly used in the relevant literature, but analyzed the written responses of the students instead because they thought students might not be able to depict all their knowledge in drawings, which would reduce the reliability of the analysis. The relevant literature includes many discussions of children's drawings of either what they know or have seen (Beal \& 
Arnold, 1990; Freeman \& Janikoun, 1972). This means that it is difficult to determine whether children really know that subject or not by analyzing their drawings, and there might be differences in figures because of mental images (see. Bassett, 1977). Moreover, Reiss, Tunnicliffe, Andersen, Bartoszeck et al. (2002) used the drawing technique in their studies and determined that the best way to analyze drawings might not be clear since students also express their feelings in them.

For these reasons, this study's author aimed to identify what students know about body organs and systems by analysing their written responses to questions. All the studies referred to by this study have found that students have misconceptions about body organs and systems, but fail to consider the causes of these misconceptions adequately. By doing so, the author hopes to contribute to the relevant literature. We confront the subject of body organs and systems both in our daily lives and in the life sciences. Identifying students' knowledge levels in this subject will help to determine their misconceptions and fill gaps in their training as scientifically literate individuals, to evaluate the relationship between students' knowledge levels and the education system and suggestions based on these findings will contribute to the field of biology pedagogy.

\section{The Purpose of the Study}

This study researches high school students' familiarity with body organs and knowledge about the systems to which they belong. It also identifies their misconceptions and deficiencies and discusses their causes. Given the goals of the study, the researchers sought answers to these questions:

1. Are high school students able to list the names of their bodies' organs?

2. How much do high school students know about the systems in the human body to which these organs belong?

3. To what extent do students know about the primary functions of the organs?

\section{Methodology of Research}

\section{Sample of Research}

The sample of the study included 244 students in the four Anatolian high schools in the city of Kars, Turkey. Turkey's Anatolian high schools have four-year programs to prepare students for higher education according to their interests, talents and abilities. In addition, the same standard curriculum is used by all the Anatolian high schools in Turkey. The researchers randomly selected one group from each high school in the sample from the ninth, tenth, eleventh and twelfth grade levels, and all students in these groups were included in the sample. The students in these groups mainly take science courses. There were no major differences between the schools in demographic and socio-cultural characteristics. Since there were fewer students in the eleventh and twelfth grade groups, there were not as many students from these groups as the other grade levels. The twelfth grade students tend to have poor school attendance since they are preparing for the national university entrance examination. Table 1 exhibits the demographical features of the sample.

Table 1: The demographical features of the sample

\begin{tabular}{llll}
\hline Demographical features & & $\mathrm{N}$ & $\%$ \\
\hline Class & 9 & 63 & 25.81 \\
\cline { 2 - 4 } & 10 & 98 & 40.16 \\
\cline { 2 - 4 } & 11 & 43 & 17.62 \\
\hline Gender & Total & 40 & 16.39 \\
\hline & Female & 1244 & 100 \\
\cline { 2 - 4 } & Male & 120 & 49.18 \\
\cline { 2 - 4 } & Total & 244 & 100 \\
\hline
\end{tabular}


The study data were collected from the students in their own classrooms. Before filling out the measurement tool, the researchers informed the students about the objective of the study and assured them that their personal information would be kept confidential. The researchers also told students that they could withdraw from the study any time they wished.

\section{Materials and Methods}

The study used the descriptive survey method. Accordingly, the study sample was tested using the Organs Knowledge Test (OKT). The OKT was prepared by the author. First, the author reviewed the relevant literature and decided to ask open-ended questions in order to measure the students' knowledge levels directly. Tamir (1971) suggested that open-ended questions could be an alternative to multiple-choice questions. Tamir (1971) also argued that open-ended questions were better than multiple-choice questions at eliciting students' knowledge and misconceptions. The author consulted the opinion of two biology experts and determined that it would be necessary to ask students about: (i) the names of the organs, (ii) the systems to which the organs belong and (iii) the main functions of the organs. Then, the author consulted the opinions of two science teachers and decided to format these questions hierarchically as organ-system-function. The author also checked the comprehensibility of the OKT by showing it to two high school students. After completing these validity and reliability analyses, the author asked the students to: "Write down the body organs you know, the organ systems to which they belong and their main functions in the table below."

\begin{tabular}{|l|l|l|}
\hline $\begin{array}{l}\text { Name of the } \\
\text { body organ }\end{array}$ & The system to which it belongs & Its main function \\
\hline & & \\
& & \\
\hline
\end{tabular}

The students' responses in the sections, "body organ" and "the system to which it belongs," were marked "correct" or "incorrect or no answer." The author used the classification of organs and organ systems shown in Table 2, which was also used by Prokop and Fancovicova (2006) and Reiss and Tunnicliffe (2001).

Their responses in the section, "its main function," were marked as "correct", "partially correct" and "incorrect or no answer." The author evaluated the students' responses in these three categories using these criteria:

Correct (C): The answer is scientifically correct.

Partially correct (PC): The answer includes a part of the correct answer.

Incorrect/no answer (I): The answer is not scientifically correct or no answer is provided.

For example:

"The task of the lungs is to inhale oxygen and exbale carbon dioxide" (correct answer).

"The task of the lungs is to clean the blood" (partially correct answer).

"The task of the lungs is to clean $\mathrm{CO}_{2}$ and transfer it back to the blood" (incorrect answer).

The data were analysed and encoded by two experts in biology. Another expert evaluated the consistency of these codes. The qualitative data acquired using this method were converted into quantitative data in form of frequencies and percentages. The data from each class was evaluated separately and tabulated to find out whether students' responses varied according to their grade level. 
Aydın, S. (2016). To what extent do Turkish high school students know about their body organs and organ systems? International Journal of Human Sciences, 13(1), 1094-1106. doi:10.14687/ijhs.v13i1.3498

Table 2: Organ systems and organs

\begin{tabular}{ll}
\hline Organ systems & Organs \\
\hline Respiratory system & Two lungs, two bronchi, windpipe \\
\hline Digestive system & $\begin{array}{l}\text { Through tube and mouth to anus and indication } \\
\text { of convolutions and/or compartmentalisation }\end{array}$ \\
\hline Skeletal system & Skull, spine, ribs, limbs \\
\hline Nervous system & Brain, spinal cord, some peripheral nerve \\
\hline Endocrine system & Thyroid, adrenals, pituitary \\
\hline Circulatory system & Heart, arteries and veins \\
\hline Urinary system & Two kidneys, two ureters, bladder and urethra \\
\hline Reproductive system & Two ovaries, two fallopian tubes, uterus and \\
& vagina or two testes, two ejaculatory ducts and \\
\hline Muscular system & penis \\
\hline Note. In the groups
\end{tabular}

Note. In their research, Reiss and Tunnicliffe (2001) treated the urinary and reproductive system (shown in Table 2) as a single urinogenital system. This study treats them separately, as did Prokop and Fancovicova (2006).

\section{Results and Comments}

The data acquired by analysing the students' responses were evaluated separately to answer the subproblems of the research.

\section{The organs that students listed}

The organs that the students listed are shown as percentages and frequencies separately in Table 3.

Table 3: The organs that students listed

\begin{tabular}{lllllllll}
\hline & \multicolumn{2}{l}{ 9th grade } & \multicolumn{2}{l}{ 10th grade } & \multicolumn{2}{l}{ 11th grade } & \multicolumn{2}{l}{ 12th grade } \\
\hline Organ & $\mathrm{f}$ & $\%$ & $\mathrm{f}$ & $\%$ & $\mathrm{f}$ & $\%$ & $\mathrm{f}$ & $\%$ \\
\hline Heart & 57 & 90.48 & 94 & 95.92 & 38 & 88.37 & 32 & 80 \\
\hline Lungs & 56 & 88.89 & 93 & 94.90 & 35 & 81.40 & 35 & 87.5 \\
\hline Kidneys & 56 & 88.89 & 85 & 86.73 & 31 & 72.09 & 31 & 77.5 \\
\hline Stomach & 42 & 66.67 & 81 & 82.65 & 37 & 86.05 & 31 & 77.5 \\
\hline Small intestine & 36 & 57.14 & 48 & 48.98 & 21 & 48.84 & 23 & 57.5 \\
\hline Colon & 35 & 55.56 & 47 & 47.96 & 21 & 48.84 & 18 & 45 \\
\hline Liver & 24 & 38.10 & 61 & 62.24 & 30 & 69.77 & 24 & 60 \\
\hline Esophagus & 19 & 30.16 & 38 & 38.78 & 13 & 30.23 & 12 & 30 \\
\hline Urinary bladder & 9 & 14.29 & 5 & 5.10 & - & - & - & - \\
\hline Trachea & 8 & 12.70 & 27 & 27.55 & 9 & 20.93 & 6 & 15 \\
\hline Pancreas & 7 & 11.11 & 23 & 23.47 & 14 & 32.56 & 10 & 25 \\
\hline Anus & 5 & 7.94 & 8 & 8.16 & - & - & 6 & 15 \\
\hline Intestine & 5 & 7.94 & 25 & 25.51 & 12 & 27.91 & 6 & 15 \\
\hline Brain & 4 & 6.35 & 6 & 6.12 & - & - & 8 & 20 \\
\hline Mouth & 2 & 3.17 & - & - & 3 & 6.98 & - & - \\
\hline Tongue & 2 & 3.17 & - & - & - & - & - & - \\
\hline
\end{tabular}


Aydın, S. (2016). To what extent do Turkish high school students know about their body organs and organ systems? International Journal of Human Sciences, 13(1), 1094-1106. doi:10.14687/ijhs.v13i1.3498

\begin{tabular}{lllllllll}
\hline Diaphragm & 1 & 1.59 & 5 & 5.10 & 1 & 2.33 & - & - \\
\hline Spleen & 1 & 1.59 & - & - & 2 & 4.65 & - & - \\
\hline Pharynx & - & - & 6 & 6.12 & - & - & - & - \\
\hline Testes & - & - & 5 & 5.10 & - & - & 1 & 2.5 \\
\hline Ovary & - & - & 1 & 1.02 & - & - & 1 & 2.5 \\
\hline Gallbladder & - & - & 2 & 2.04 & - & - & 2 & 5 \\
\hline Muscles & - & - & 1 & 1.02 & - & - & - & - \\
\hline Urethra & - & - & - & - & 3 & 6.98 & 1 & 2.5 \\
\hline Blood vessel & - & - & - & - & 1 & 2.33 & - & - \\
\hline
\end{tabular}

Note. $\mathrm{f}=$ The number of the students who wrote the name of the organ and $\%=$ the rate of the students who wrote the name of the organ.

Although there were small differences between the classes in identifying the organs, the heart, lungs, stomach and kidneys were the most widely listed organs in all the classes. The general order of the organs (Figure 1) indicates that the most widely listed organ in the human body is the heart. The lungs, kidneys and stomach are ranked next (The organs that were only written twice or less are not shown in Figure 2 to prevent confusion).

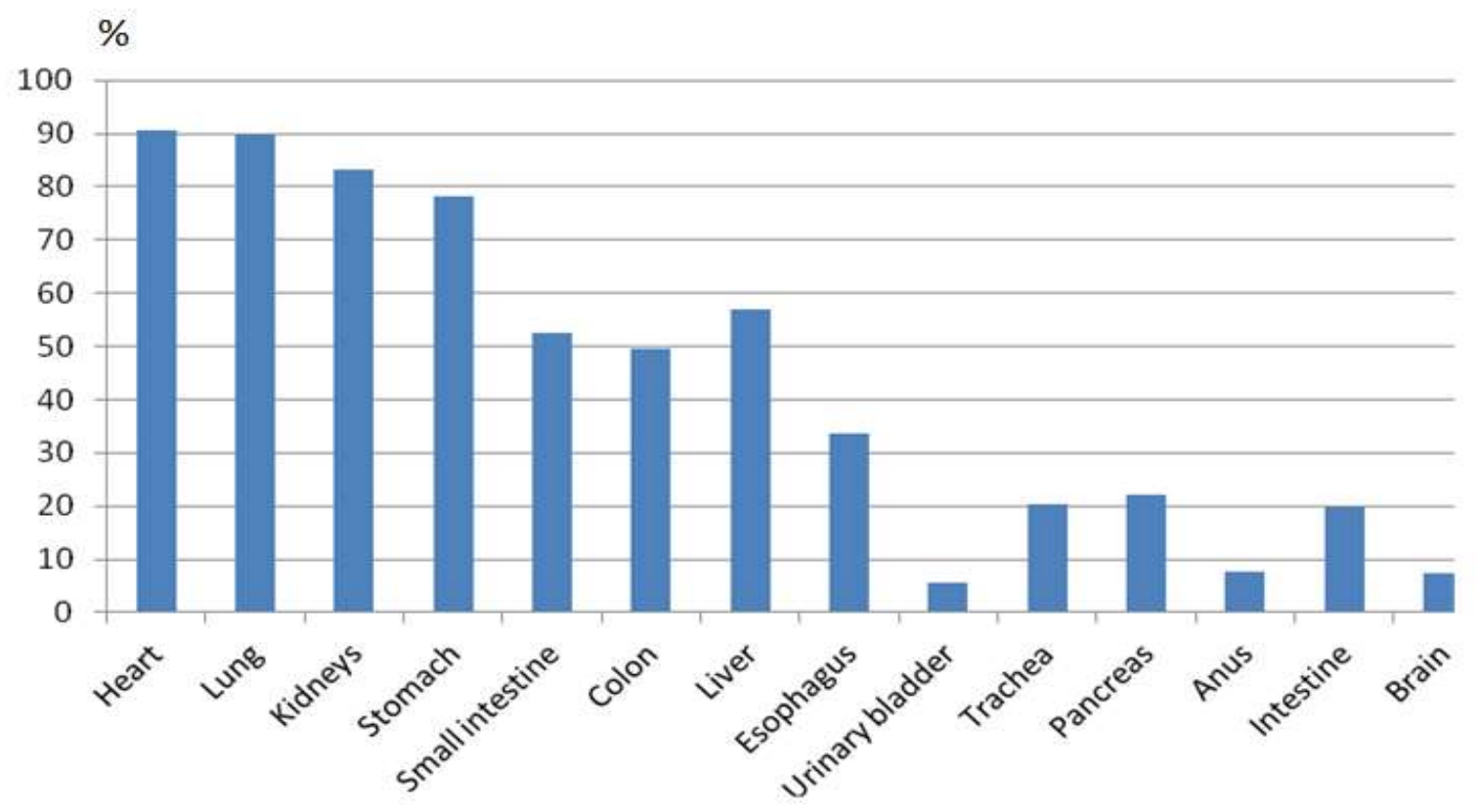

The names of the organs that students listed

Figure 1. The body organs best known by the students

Table 3 and Figure 1 show that the organs that are most widely listed by the students are those that are most involved in our daily lives. They belong to the circulatory, respiratory, urinary and digestive systems. Moreover, most of the organs identified by the students are in the digestive system. It was found that the students know about the organs in only four of the nine systems in the human body, and that they might not be considering other body organs as body organs.

\section{The students' knowledge about the systems to which body organs belong}

The students were also asked to write down the system to which the organ they identified belonged, and these responses were graded. In this section, the author made an effort to determine 
Aydın, S. (2016). To what extent do Turkish high school students know about their body organs and organ systems? International Journal of Human Sciences, 13(1), 1094-1106. doi:10.14687/ijhs.v13i1.3498

to what extent students who gave the correct name of the organ was informed about the organ system to which the organ belongs.

Table 4: The students' responses concerning the organ systems to which body organs belong

\begin{tabular}{|c|c|c|c|c|c|c|c|c|c|}
\hline \multirow[t]{2}{*}{ Organ } & \multicolumn{2}{|c|}{ 9th grade } & \multicolumn{2}{|c|}{ 10th grade } & \multicolumn{2}{|c|}{ 11th grade } & \multicolumn{2}{|c|}{ 12th grade } & \multirow{2}{*}{$\begin{array}{l}\text { Most frequently given } \\
\text { incorrect answers }\end{array}$} \\
\hline & $\mathrm{f}$ & $\%$ & $\mathrm{f}$ & $\%$ & $f$ & $\%$ & $\mathrm{f}$ & $\%$ & \\
\hline Heart & 47 & 82.45 & 89 & 94.68 & 36 & 94.73 & 32 & 100 & \\
\hline Lungs & 50 & 89.28 & 90 & 96.77 & 35 & 100 & 28 & 80 & \\
\hline Kidneys & 49 & 87.5 & 77 & 95.06 & 28 & 90.32 & 28 & 90.32 & \\
\hline Stomach & 30 & 71.42 & 77 & 90.58 & 33 & 89.18 & 30 & 96.77 & \\
\hline Small intestine & 19 & $52.77^{\mathrm{a}}$ & 33 & $68.75^{a}$ & 10 & $47.61^{\mathrm{a}}$ & 19 & 82.60 & ${ }^{a}$ Excretory system \\
\hline$\overline{\text { Colon }}$ & 9 & $25.71^{a}$ & 16 & $34.04^{\mathrm{a}}$ & 7 & $33.33^{a}$ & 10 & $55.55^{\mathrm{a}}$ & ${ }^{a}$ Excretory system \\
\hline Liver & 1 & $4.16^{\mathrm{a}, \mathrm{b}}$ & 32 & $52.45^{\mathrm{a}, \mathrm{b}}$ & 12 & $40^{\mathrm{a}, \mathrm{b}}$ & 20 & 83.33 & $\begin{array}{l}{ }^{\mathrm{a}} \text { Excretory system } \\
{ }^{\mathrm{b}} \text { Circulatory system }\end{array}$ \\
\hline Esophagus & 16 & 84.21 & 34 & 89.47 & 19 & 92.30 & 10 & 83.33 & \\
\hline Urinary bladder & 9 & 100 & 5 & 100 & - & - & - & - & \\
\hline Trachea & 8 & 100 & 25 & 92.59 & 6 & 66.66 & 6 & 100 & \\
\hline Pancreas & 1 & $14.28^{\mathrm{a}}$ & 14 & $60.86^{a}$ & 9 & $64.28^{\mathrm{a}}$ & 10 & 100 & ${ }^{a}$ Excretory system \\
\hline$\overline{\text { Anus }}$ & 0 & $0^{\mathrm{a}}$ & 0 & $0^{a}$ & - & - & 1 & $16.6^{\mathrm{a}}$ & ${ }^{a}$ Excretory system \\
\hline Intestine & 1 & $20^{a}$ & 10 & $40^{a}$ & 3 & $25^{a}$ & 3 & $50^{a}$ & ${ }^{a}$ Excretory system \\
\hline Brain & 2 & 50 & 6 & 100 & - & - & 7 & 87.5 & \\
\hline
\end{tabular}

${ }^{\mathrm{a}, \mathrm{b}}$ Most frequently given incorrect answers

Note. The percentages were calculated using the number of students who identified the organ (Table 3), and they indicate the proportion of the students who correctly identified the system to which the organ belongs.

An analysis of Table 4 indicates that the majority of the students who identified the heart, lungs, kidney, stomach and esophagus also knew the systems to which these organs belong. The students who identified the small intestine, intestine, liver, pancreas, and anus had a lower proportion of correct answers. Most of the students who did not know the systems to which these organs belong guessed that they belong to the excretory system (urinary system). However, all these organs are parts of the digestive system, and the percentage of students who thought that they are included in the excretory system was high, specifically in the ninth, tenth and eleventh grade levels. The twelfth graders had a slightly higher proportion of correct answers.

The educational system may be responsible for this situation. In the primary and secondary level curricula taught nationwide in Turkey, students are taught the excretory system as the urinary system from primary school until high school. The subject of body organs and systems is included in the twelfth grade biology curriculum, and the term "urinary system" is used instead of "excretory system". Thus, students use the word "excretory" until twelfth grade, and they are led to believe that the small intestine, colon and anus are parts of the excretory system that eliminates solid waste from the body. This situation leads to many misconceptions. An analysis of the seventh grade science and technology curriculum and the twelfth grade biology curriculum indicates that the role of the liver in excretion is also considered (MEB, 2006; MEB, 2011). This might be the reason that students tend to regard the liver as part of the excretory system. These misconceptions can be removed by using the term "urinary system" instead of "excretory system" in textbooks. 
Aydın, S. (2016). To what extent do Turkish high school students know about their body organs and organ systems? International Journal of Human Sciences, 13(1), 1094-1106. doi:10.14687/ijhs.v13i1.3498

\section{The students' knowledge about the main functions of body organs}

The students were also asked to explain the main function of the organs they identified. The students' responses were marked as "correct", "partially correct" and "incorrect or no answer." Data were analysed and tabulated for each class.

Table 5: Ninth grade students' responses concerning the main functions of body organs

\begin{tabular}{lllllll}
\hline Organ & correct & & partially correct & \multicolumn{2}{c}{$\begin{array}{l}\text { incorrect } \\
\text { answer }\end{array}$} & or no \\
\hline Heart & $\mathrm{f}$ & $\%$ & $\mathrm{f}$ & $\%$ & $\mathrm{f}$ & $\%$ \\
\hline Lungs & 51 & 89.47 & - & - & 6 & 10.52 \\
\hline Kidneys & 36 & 64.28 & 10 & 17.85 & 10 & 17.85 \\
\hline Stomach & 29 & 51.78 & 16 & 28.57 & 11 & 19.64 \\
\hline Small intestine & 24 & 57.14 & 10 & 23.80 & 8 & 19.04 \\
\hline Colon & 15 & 41.66 & 9 & 25 & 12 & 33.33 \\
\hline Liver & 22 & 62.85 & 3 & 8.57 & 10 & 28.57 \\
\hline Esophagus & 5 & 20.83 & - & - & 19 & 79.16 \\
\hline Urinary bladder & 19 & 100 & - & - & - & - \\
\hline Trachea & 2 & 22.22 & - & - & 7 & 77.77 \\
\hline Pancreas & 5 & 62.5 & 3 & 37.5 & - & - \\
\hline Anus & 2 & 28.57 & - & - & 5 & 71.4 \\
\hline Intestine & 2 & 40 & - & - & 3 & 60 \\
\hline Brain & 1 & 20 & 3 & 60 & 1 & 20 \\
\hline
\end{tabular}

Note. The percentages were calculated using the number of students who identified the organ (Table 3).

An analysis of Table 5 indicates that students who identified the esophagus, heart, lungs, colon and trachea knew the functions of these organs. On the other hand, a majority of students who identified the liver, urinary bladder and pancreas did not know the functions of these organs. The liver has various functions, one reason why a variety of incorrect responses were given for it. Here are some of the students' incorrect responses about the function of the liver:

"It stores the urea."

"It cleans contaminated blood."

"It excretes the food the body does not need."

Table 6: Tenth grade students' responses concerning the main functions of organs

\begin{tabular}{lllllll}
\hline Organ & correct & & partially correct & \multicolumn{2}{l}{ incorrect or no answer } \\
\hline Heart & $\mathrm{f}$ & $\%$ & $\mathrm{f}$ & $\%$ & $\mathrm{f}$ & $\%$ \\
\hline Lungs & 88 & 93.61 & - & - & 6 & 6.38 \\
\hline Kidneys & 50 & 53.76 & 29 & 31.18 & 14 & 15.05 \\
\hline Stomach & 46 & 54.11 & 16 & 18.82 & 23 & 27.05 \\
\hline Small intestine & 72 & 88.89 & - & - & 9 & 11.11 \\
\hline Colon & 25 & 52.08 & 6 & 12.5 & 17 & 35.41 \\
\hline
\end{tabular}


Aydın, S. (2016). To what extent do Turkish high school students know about their body organs and organ systems? International Journal of Human Sciences, 13(1), 1094-1106. doi:10.14687/ijhs.v13i1.3498

\begin{tabular}{lllllll}
\hline Liver & 29 & 47.54 & 4 & 6.55 & 28 & 45.90 \\
\hline Esophagus & 30 & 78.94 & - & - & 8 & 21.05 \\
\hline Urinary bladder & 5 & 100 & - & - & - & - \\
\hline Trachea & 17 & 62.96 & 5 & 18.51 & 5 & 18.51 \\
\hline Pancreas & 16 & 69.56 & - & - & 7 & 30.43 \\
\hline Anus & 8 & 100 & - & - & - & - \\
\hline Intestine & 10 & 40 & 9 & 36 & 6 & 24 \\
\hline Brain & 6 & 100 & - & - & - & - \\
\hline
\end{tabular}

Note. The percentages were calculated using the number of students who identified the organ (Table 3).

Table 6 indicates that most tenth grade students who identified the bladder, anus, brain, heart, stomach, esophagus and pancreas knew the functions of these organs. The most considerable finding is that they did not know the functions of the liver, pancreas and small intestine. Here are some of the students' incorrect responses:

"The task of the liver is to excrete waste from the body."

"The task of the pancreas is to digest food."

"The task of the small intestine is to convey blood to the heart."

Table 7: Eleventh grade students' responses concerning the main functions of organs

\begin{tabular}{lllllll}
\hline Organ & correct & & partially correct & \multicolumn{2}{c}{$\begin{array}{l}\text { incorrect } \\
\text { answer }\end{array}$} & or no \\
\hline Heart & $\mathrm{f}$ & $\%$ & $\mathrm{f}$ & $\%$ & $\mathrm{f}$ & $\%$ \\
\hline Lungs & 35 & 92.10 & 1 & 2.63 & 2 & 5.26 \\
\hline Kidneys & 25 & 71.42 & 2 & 5.71 & 8 & 22.85 \\
\hline Stomach & 21 & 67.74 & 1 & 3.22 & 9 & 29.03 \\
\hline Small intestine & 31 & 83.78 & 2 & 5.40 & 4 & 10.81 \\
\hline Colon & 6 & 28.57 & 8 & 38.09 & 7 & 33.33 \\
\hline Liver & 7 & 33.33 & 11 & 52.38 & 3 & 14.28 \\
\hline Esophagus & 6 & 20 & 2 & 6.66 & 22 & 73.33 \\
\hline Urinary bladder & 10 & 76.92 & 2 & 15.38 & 1 & 7.69 \\
\hline Trachea & - & - & - & - & - & - \\
\hline Pancreas & 3 & 33.33 & - & - & 6 & 66.66 \\
\hline Anus & 8 & 57.14 & - & - & 6 & 42.85 \\
\hline Intestine & - & - & - & - & - & - \\
\hline Brain & - & - & 1 & 8.33 & 11 & 91.66 \\
\hline Net The percen
\end{tabular}

Note. The percentages were calculated using the number of students who identified the organ (Table 3).

Table 7 indicates that eleventh grade students who identified the heart, stomach, esophagus, lungs and kidneys knew the functions of these organs. The most considerable finding is that the students who identified the intestines, liver and trachea did not know the functions of these organs. Here are some of the students' incorrect responses:

"The task of the intestine is to play a role in the excretion system." 
Aydın, S. (2016). To what extent do Turkish high school students know about their body organs and organ systems? International Journal of Human Sciences, 13(1), 1094-1106. doi:10.14687/ijhs.v13i1.3498

"The task of the liver is to clean the blood."

"The task of the trachea is to digest food."

Table 8: Twelfth grade students' responses to the questions about main functions of organs

\begin{tabular}{lllllll}
\hline Organ & correct & & partially correct & \multicolumn{2}{l}{ incorrect or no answer } \\
\hline Heart & $\mathrm{f}$ & $\%$ & $\mathrm{f}$ & $\%$ & $\mathrm{f}$ & $\%$ \\
\hline Lungs & 31 & 96.87 & - & - & 1 & 3.12 \\
\hline Kidneys & 29 & 82.85 & 2 & 5.71 & 4 & 11.42 \\
\hline Stomach & 29 & 93.54 & - & - & 2 & 6.45 \\
\hline Small intestine & 28 & 90.32 & - & - & 3 & 9.67 \\
\hline Colon & 17 & 73.91 & 3 & 13.04 & 3 & 13.04 \\
\hline Liver & 14 & 77.77 & - & - & 4 & 22.22 \\
\hline Esophagus & 12 & 50 & 3 & 12.5 & 9 & 37.5 \\
\hline Urinary bladder & 10 & 83.33 & 1 & 8.33 & 1 & 8.33 \\
\hline Trachea & - & - & - & - & - & - \\
\hline Pancreas & 3 & 50 & 2 & 33.33 & 1 & 16.66 \\
\hline Anus & 10 & 100 & - & - & - & - \\
\hline Intestine & 4 & 66.66 & - & - & 2 & 33.33 \\
\hline Brain & - & - & - & - & 6 & 100 \\
\hline Note. The percenta & 6 & 75 & - & - & 2 & 25 \\
\hline
\end{tabular}

Note. The percentages were calculated using the number of students who identified the organ (Table 3).

An analysis of Table 8 indicates that twelfth grade students do not have any difficulty with the functions of organs. Most significantly, none of the students who identified the intestine had a comprehensive knowledge about the functions of this organ. However, the students who identified small intestine and colon did not have this problem.

A general analysis of all grades indicates that twelfth grade students identified the functions of body organs more correctly. The proportion of students who wrote the liver's functions correctly increases, especially among twelfth grade students. However, it was found that the students' knowledge about the functions of the liver was insufficient in all the grades. An analysis of the students' responses indicated that the most frequent correct responses about the tasks of the liver were:

"It transforms ammonia into urea" (26 students-10.6\%).

The students who wrote that the liver transformed the ammonia into urea also thought that the liver was included in the excretory system:

"It deactivates the poisonous substances in the body" (15 students-6.1\%).

"It supports digestion" (14 students-5.7\%).

"It stores the extra glucose" (6 students-2.4\%).

"It digests fat" (5 students-2.04\%).

"It secretes bile" (5 students-2.04\%).

In addition, most students have-although it is minor-difficulty explaining the functions of the small intestine and colon. When the students' responses are evaluated, it can be seen that this difficulty results from the students' regarding these organs as parts of the excretory system and thinking that they are responsible for excretion. The students who thought that these organs were included in the excretory system gave these responses: 
"The task of the intestine is to excrete the waste created by digestion" (twelfth grade).

"The task of the large intestine is to eliminate food waste from the body" (eleventh grade).

"The task of the small intestine is to excrete waste from the body" (tenth grade)

"The task of the small intestine is to excrete food waste from the body" (ninth grade).

\section{Discussion and Educational Implications}

This study examines the knowledge levels of high school students about the organs of the human body and organ systems and their misconceptions and deficiencies in this subject. The primary outcomes of the study is that the heart, lungs, kidneys and stomach are the organs best known by the students, and that they most often identified organs in the circulatory, respiratory, urinary and digestive systems. An analysis of all the students' knowledge about organs and systems indicates that the organs that students identified are those that are most-involved in our daily lives. According to the Turkish Statistical Institute (TurkStat), circulatory system diseases were the leading cause of death in 2013 and 2014 in Turkey, and respiratory system diseases were the third cause of death (TurkStat, 2015). Thus, the reason that the heart and lungs were better known might be the fact that diseases related to these organs are very common in Turkey.

Teixeira (2000) states that children above the age of eight know about all the organs in the abdominal cavity. In contrast with this fact, that study indicated that only one or two students identified muscles, blood vessels or the ovary, and no students identified organs in the endocrine and skeletal systems. In addition, there are other studies reaching similar results in the relevant literature (Bortoszeck, Machado, Amann-Gainotti, 2008; Prokop and Fancovicova, 2006). People in different cultures provided almost the same results, which suggests that the results of this study are not based on culture. Moreover, the subject of body organs and systems being included in the twelfth grade biology curriculum reveals that younger students' knowledge about the body organs may be affected by their daily lives and their earlier schooling.

When the results of each grade are analysed separately, there are no considerable differences between the ninth, tenth, eleventh grade classes and the twelfth grade students' knowledge and misconceptions, even though the twelfth grade students are taught about organs and organ systems in their biology courses. Moreover, students of all grades identified more or less the same organs in their responses. The only salient difference is that the twelfth grade students gave more correct responses concerning the organs' functions. The subject of organs and organ systems is included in the Turkish national biology curriculum, but students have only the information they learn in primary education and from their environment until the twelfth grade, and they are unable to correct their misconceptions then. Güngör and Özgür (2009) conducted a study in Turkey with fifth grade students and found that students confused the terms "excretory waste" and "digestive waste," and they thought that the digestive tract after the stomach was an organ in the excretory system. Like this study, this finding indicates that this misconception was taught in primary schools and was still not corrected in the twelfth grade. The author suggests that body organs and organ systems be taught at an early stage of education using the term "urinary system" instead of "excretory system." In particular, the tasks of the organs should be emphasised in order to reduce misconceptions.

A review of the literature indicates that, similarly, the systems that are most successfully drawn by students are the digestive and circulatory systems, while the most frequently drawn body organ is the heart (Reiss \& Tunnicliffe, 2001; Reiss et al., 2002). Prokop and Fancovicova (2006) did research with university students and found that more than half of the drawings included the heart, lungs and stomach. Bartoszeck, Machado and Amann-Gainotti (2008) found that the heart and lungs were the most frequently identified organs, while the digestive and respiratory systems were the most commonly identified organ systems.

Another outcome of the research is that a majority of the students who identified the small intestine, intestine, liver, pancreas, anus and intestine thought that these organs were parts of the 
excretory system (urinary system). The organs' functions and the relationship between organs and systems should be taught appropriately to prevent students from thinking that these organs are included in the excretory system since they are in reality parts of the digestive system. In the relevant literature, studies indicate that students in general are informed about the organs in the human body; however, they fail to situate them in systems and build relationships between them (Cuthbert, 2000; Özsevgeç, 2007; Reiss et al., 2002).

While the twelfth grade students are better-informed about the functions of body organs, they have difficulty explaining the functions of organs that resemble each other such as the liver, colon, small intestine, intestine and anus. The liver is a very important organ in the human body with a variety of functions. For this reason, students wrote down different functions for the liver. This may have increased the numbers of incorrect answers. On the other hand, when the students' responses were analysed, it was found that they incorrectly identified the functions of the colon, small intestine, intestine and anus because they regarded them as parts of the excretory system. These results indicate that digestion and excretion need to be emphasised more in the curriculum. Prokop and Fancovicova (2006) and Özsevgeç (2007) claim that students are informed about the organs in general, but have deficiencies regarding their functions. In addition, the author found that the incorrect information taught in primary and high schools frequently causes misconceptions in high school. Universal concepts should be used to teach science at all levels in this age of science and technology.

\section{References}

Atılboz, N. G. (2004). Lise 1. Sınıf Öğrencilerinin Mitoz ve Mayoz Bölünme Konuları İle İlgili Anlama Düzeyleri ve Kavram Yanilgilar1 [9th Grade Students' Understanding Levels and Misconceptions about Mitosis and Meiosis]. Gari Ë̆itim Fakültesi Dergisi, 24(3), 147-157.

Bahar, M. (2002). Students' learning difficulties in biology: Reasons and solutions. Kastamonu Eğitim Fakültesi Dergisi, 10(1), 73-82.

Bartoszeck, A. B., Machado, D. Z., \& Amann-Gainotti, M. (2008). Representations of internal body image: A study of preadolescents and adolescent students in Araucaria, Paraná, Brazil. Ciências \& Cognição, 13(2), 139-159.

Bassett, E. M. (1977). Production strategies in the child's drawing of the human figure: Towards an argument for a model of syncretic perception. In G. Butterworth (Ed.), The child's representation of the World (pp. 49-59). New York: Plenum.

Beal, C. R., \& Arnold, D. S. (1990). The effect of instructions on view-specificity in young children's drawing and picture selection. British Journal of Developmental Psychology, 8, 393-400.

Cuthbert, A. J. (2000). Do children have a holistic view of their internal body maps? School Science Review, 82(299), 25 - 32. Durant, J. R. (1993). What is scientific literacy? In J. R. Durant and J. Gregory (Ed.), Science and culture in Europe (pp. 129-137). London: Science Museum.

Freeman, N. H., \& Janikoun, R. (1972). Intellectual realism in children's drawings of a familiar object with distinctive features. Child Development, 43, 1116-1121.

Gellert, E. (1962). Children's conceptions of the content and functions of the human body. Genetic Psychology Monographs, 65, 293-405.

Güneş, M. H., \& Güneş, T. (2005). İlköğretim öğrencilerinin biyoloji konularını anlama zorlukları ve nedenleri [Difficulties and their reasons in learning biology concepts in primary school students]. Kirşehir Ë̆gitim Fakültesi Dergisi, 6(2), 169-175.

Güngör, B., \& Özgür, S. (2009). İlköğretim beşinci sınıf öğrencilerinin sindirim sistemi konusundaki didaktik kökenli kavram yanılgılarının nedenleri [The Causes of the Fifth Grade Students Misconceptions Originated From Didactic About Digestive System]. Necatibey Eğitim Fakültesi Elektronik. Fen ve Matematik Eüitimi Dergisi, 3(2), 149-177.

Jaakkola, R. O., \& Slaughter, V. (2002). Children's body knowledge: Understanding "life" as a biological goal. British Journal of Developmental Psychology, 20, 325-342. 
Johnson, C. N., \& Wellman, H. M. (1982). Children's developing conceptions of the mind and brain. Child Development, 53, 222-234.

MEB. (2006). İlköğretim Fen ve Teknoloji Dersi (6, 7 ve 8. Sınıflar) öğretim programı $[6,7$ and 8th grade science and technology curriculum]. Millî Eğitim Bakanlığ Talim ve Terbiye Kurulu Başkanlığı, Ankara.

MEB. (2011). Ortaöğretim 12. sınıf biyoloji dersi öğretim programı [12th grade biology curriculum]. Millì Eğitim Bakanlığ Talim ve Terbiye Kurulu Başkanlığı, Ankara.

Özsevgeç, L. C. (2007). What do Turkish students at different ages know about their internal body parts both visually and verbally? Turkish Science Education, 4(2), 31-44.

Patrick, P. G., \& Tunnicliffe, S. D. (2010). Science teachers' drawings of what is inside the human body. Journal of Biological Education, 44 (2), 81-87.

Prokop, P., \& Fancovicova, J. (2006). Students' ideas about the human body: Do they really draw what they know? Journal of Baltic Science Education, 2 (10), 86-95.

Reiss, M. J., \& Tunnicliffe, S. D. (2001). Students' understandings of human organs and organ systems. Research in Science Education, 31, 383-399.

Reiss, M. J., Tunnicliffe, S. D., Andersen, A. M., Bartoszeck, A., Carvalho, G. S., Chen, S. Y., Jarman, R., Jónsson, S., Manokore, V., Marchenko, N., Mulemwa, J., Novikova, T., Otuka, J., Teppa, S., \& Rooy, W. (2002) An international study of young peoples' drawings of what is inside themselves. Journal of Biological Education, 36, 58-64.

Tamir, P. (1971). An alternative approach to the construction of multiple choice test items. Journal of Biological Education, 5(6), 305-307.

Teixeira, M. F. (2000). What happens to the food we eat? Children's conceptions of the structure and function of the digestive system. International Journal of Science Education, 22 (5), 507-520.

Tekkaya, C., Çapa, Y., \& Yılmaz, Ö. (2000). Biyoloji öğretmen adaylarının genel biyoloji konularındaki kavram yanılg1ları. Hacettepe Üniversitesi Ë̈itim Fakültesi Dergisi, 18, 140-147.

TurkStat, (2015). Türkiye istatistik kurumu [Turkish Statistical Institute]. Retrieved from http://www.tuik.gov.tr/PreHaberBultenleri.do?id=18855

Yeşilyurt, S., \& Gül, Ş. (2012). Secondary School Students' Misconceptions About the "Transportation and Circulatory Systems" Unit. Journal of Theoretical Educational Science, 5(1), $17-48$. 